\title{
Ryukyum, a new genus of terrestrial crab from the Ryukyu Islands (Brachyura: Potamidae)
}

\author{
Peter K. L. Ng and Shigemitsu Shokita
}

\begin{abstract}
A new genus, Ryukyum, is established for the terrestrial potamid crab from Ishigaki and Iriomote Islands, the southern Ryukyus, Japan, Nanhaipotamon yaeyamense Minei, 1973. The new genus differs from Nanhaipotamon s. str. in the structure of the sternum, third maxilliped, male abdomen, and male first and second gonopods.
\end{abstract}

\section{Introduction}

Fourteen species of freshwater and terrestrial crabs of the family Potamidae are known from Japan. They belong to three genera - Geothelphusa Stimpson, 1858, Candidiopotamon Bott, 1968, and Nanhaipotamon Bott, 1968. Most of the species occur in the Ryukyu Islands, the southern islands of Japan (Minei, 1973).

In the genus Nanhaipotamon, two species have been reported from Japan, both from the Ryukyus - N. globosum (Parisi, 1916) and N. yaeyamense Minei, 1973. Nanhaipotamon globosum was supposedly described from Okinawa Island, but the species has never been reported from the Ryukyus despite the many studies which have been done there. Bott's (1970) records of $N$. globosum from Hong Kong are in error ( $\mathrm{Ng} \&$ Dudgeon, 1992: 743). Ng \& Dudgeon (1992: 744) suggested that $N$. globosum is not a species of Nanhaipotamon and should be referred to the genus Potamon. Whether $N$. globosum is actually found in Okinawa is not known. Nanhaipotamon yaeyamense was described from Ishigaki and Iriomote Islands by Minei (1973). The taxonomic po- sition of this terrestrial crab had been questioned by $\mathrm{Ng} \&$ Dudgeon (1992) and Ng \& Takeda (1992), who suggested that it should be transferred to its own genus. Nanhaipotamon yaeyamense is here formally referred to its own genus, Ryukyum new genus. The diagnosis of this new genus and its taxonomy forms the basis of the present paper.

The terms G1 and G2 are used for the male first and second gonopods respectively. All measurements are of the width and length respectively. Specimens are deposited in the National Science Museum, Tokyo (NSMT) and the Zoological Reference Collection (ZRC), Department of Zoology, National University of Singapore.

\section{Taxonomy \\ Potamidae}

Ryukyum new genus

Type species. - Nanhaipotamon yaeyamense Minei, 1973, by present designation.

Diagnosis. - Carapace inflated laterally and longitudinally, dorsal surfaces smooth. Epigastric cristae very low; postorbital cristae distinct but not sharp, progressively stronger as it approaches lateral margin, confluent with epibranchial teeth. External orbital angle acutely triangular; separated from anterolateral margin by distinct cleft. Anterolateral margins strongly arcuate, epibranchial tooth distinct, blunt. Exopod of third maxilliped with vestigial flagel- 


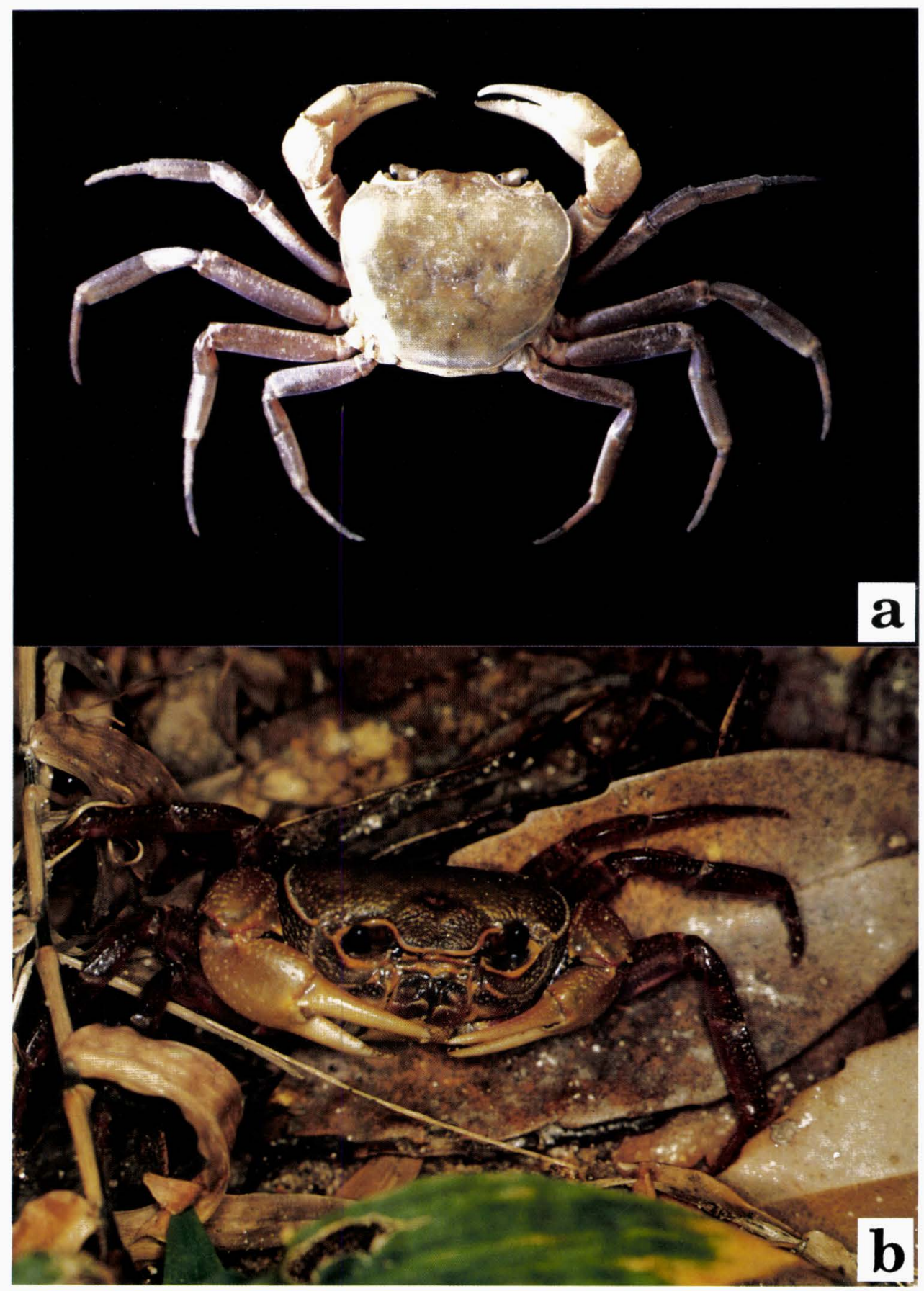

Fig. 1. Ryukyum yaeyamense. Male, 41.7 by 33.9 mm (ZRC 1994.4452): a, colour when freshly dead (photograph J.Y. Shy); b, living colours. 
lum. Suture between sternites 2 and 3 hardly discernible; all other sutures not visible; male abdomen reaching beyond an imaginary line joining bases of coxae of chelipeds. Male abdomen broadly triangular; telson slightly longer than segment 6. G1 relatively stout, gently sinuous; terminal segment short, ca. 0.2 times length of subterminal segment, gently curved outwards; base of terminal segment with bulbous structure on ventral surface; synovial membrane dorsal, broad. G2 with long distal segment, ca. 0.3 times length of basal segment.

Etymology. - The genus name is derived from the name of the Ryukyu Islands. Gender neuter.

Remarks. - The genus Nanhaipotamon Bott, 1968, was established (as a subgenus of Isolapotamon Bott, 1968) for three species of freshwater and terrestrial crabs from Japan, Taiwan and the Philippines (Bott, 1968, 1970). All are characterised by a short, stout G1 with a flattened terminal segment. New species from mainland China and southern Japan were subsequently referred to this genus (Dai et al., 1979; Dai \& Chen, 1979, 1987; Minei, 1973). Ng \& Dudgeon (1992), Ng \& Takeda (1992) and Dai \& Ng (1994) however, re-evaluated the generic position of the constituent species, and most have been transferred to other genera, with Nanhaipotamon s. str. now containing only two species from Hong Kong, mainland China and Taiwan (see Ng \& Dudgeon, 1992). The Philippine species (N. balssi Bott, 1968) was referred to Mindoron Ng \& Takeda, 1992, while most of the species from mainland China (see Dai et al., 1979; Dai \& Chen, 1979, 1987) were referred to Huananpotamon Dai \& $\mathrm{Ng}, 1994$.

The single Nanhaipotamon species described from the Yaeyama Islands in southern Japan, N. yaeyamense Minei, 1973, while it has the general swollen physiognomy of Nanhaipotamon s. str., differs markedly in many aspects from $N$. formosanum (Parisi, 1916), the type species of Nanhaipotamon. In fact, $\mathrm{Ng} \&$ Dudgeon (1992: 744) noted “... that $N$. yaeyamense is closer to crabs of the genus Geothelphusa Stimpson, 1858, especially with regards to the general form of the G1, and that it should be referred to a new genus". The present specimens of $N$. yaeyamense examined confirm that it should be referred to a separate genus. The external similarities between $N$. yaeyamense and $N$. formosanum are probably the result of convergence.

The presence of a well developed synovial membrane on the G1 clearly allies Ryukyum with Geothelphusa Stimpson, 1858. The G1s of Nanhaipotamon, Mindoron and Huananpotamon all lack synovial membranes. While the G1 of Ryukyum is much stouter than that known for any Geothelphusa species, it nevertheless has the general form and structure (cf. Bott, 1967, 1970; Minei, 1973; Shy et al., 1994). Its structure certainly differs markedly from those of Nanhaipotamon, Mindoron and Huananpotamon. Many species of Geothelphusa also have inflated carapaces like Ryukyum. The absence of a flagellum on the exopod of the third maxilliped of $R$. yaeyamense (present in all known Geothelphusa species) is probably associated with the terrestrial habits of the species. The flagellum on the exopod of the third maxilliped in species of Mindoron and Huananpotamon species are well developed, reaching the width of the merus. In Nanhaipotamon, the flagellum is short, but still several times longer than that on Ryukyum. The abdomen of Ryukyum is the broadest and most rectangular shaped of all these genera.

Ryukyum yaeyamense also bears a superficial resemblance to Geothelphusa levicervix Rathbun, 1898, from Okinawa, especially with regards to the swollen carapace. Ryukyum yaeyamense differs markedly however in the form of the carapace (hardly or no epibranchial tooth 

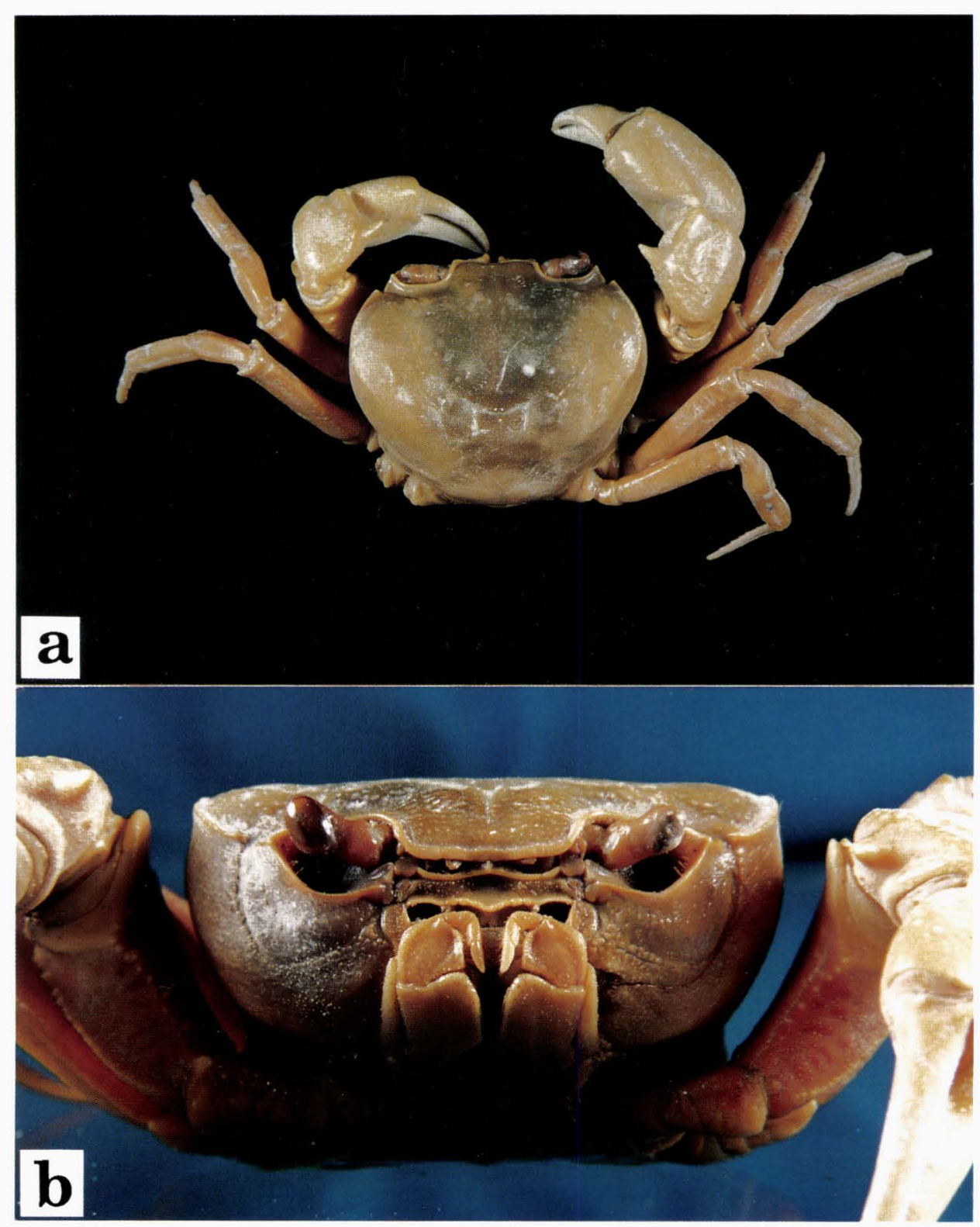

Fig. 2. Ryukyum yaeyamense. Male (41.7 by $33.9 \mathrm{~mm}$ ) (ZRC 1994.4452): a, dorsal view; b, frontal view.

present in $G$. levicervix), distinctly longer ambulatory dactyli and the much stouter G1 with a very short terminal segment (cf. Minei, 1973; unpublished data).

Ryukyum yaeyamense (Minei, 1973) new combination

(Figs. 1-3)
Nanhaipotamon yaeyamense Minei, 1973: 222, figs. 14, 15G, H; Minei, 1981: 80, pl. 4 (below); Sakai, 1976: 565, text-figs. 308a, c, c'; Miyake, 1983: 244; Shokita, 1990: 313; Shokita, $1991: 400$.

Material examined. $-2 \uparrow$ (larger 42.0 by $34.2 \mathrm{~mm}$ ) (ZRC 1994.4451), 4 ๆ (largest 33.7 by $28.8 \mathrm{~mm}$ ) (NSMT), Omoto- 

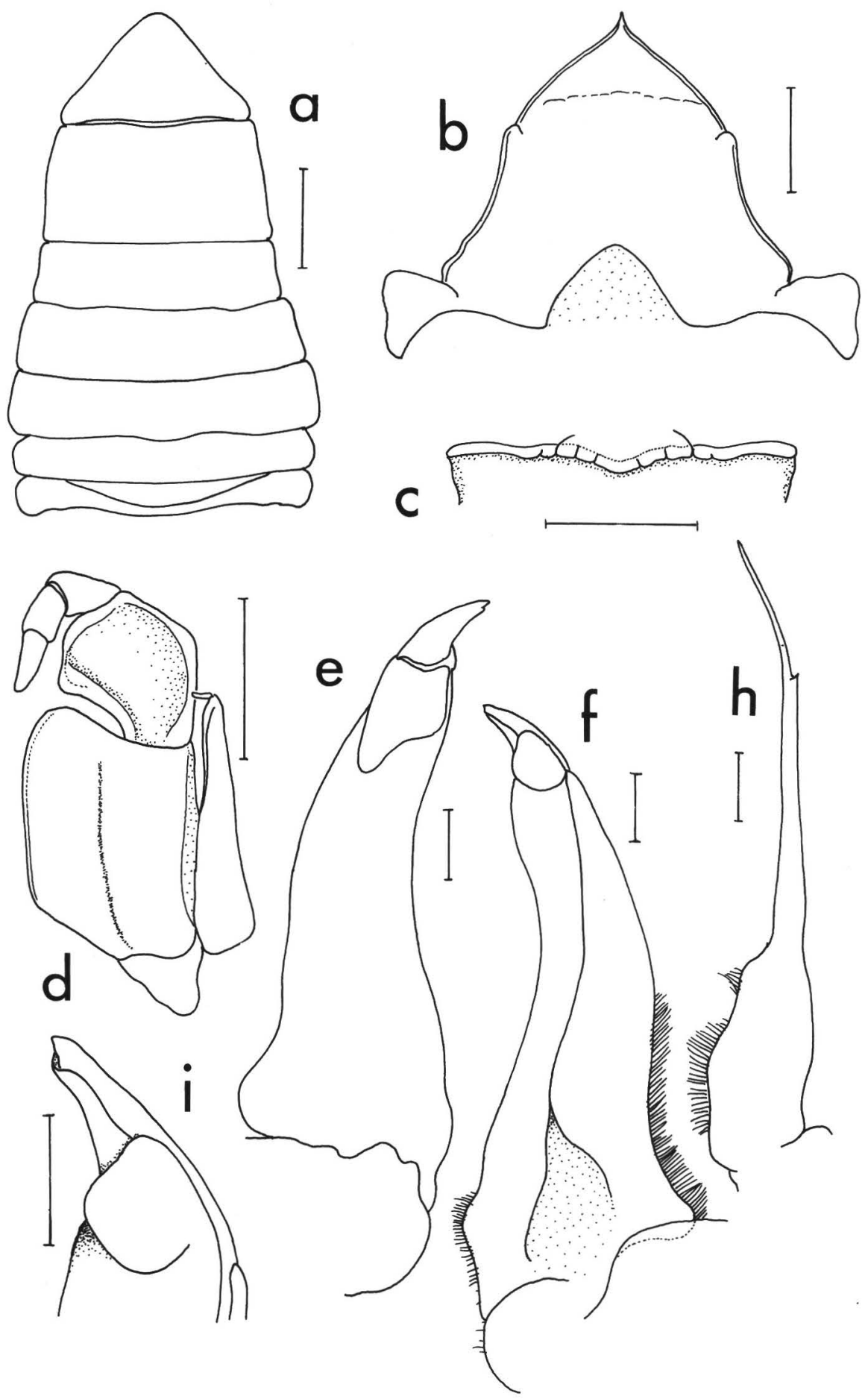

Fig. 3. Ryukyum yaeyamense. Male (41.7 by $33.9 \mathrm{~mm}$ ) (ZRC 1994.4452): a, abdomen; b, anterior sternites; c, posterior margin of epistome; $d$, left third maxilliped; e, f, right G1; g, terminal segment of right G1; h, right G2. e, dorsal view; $f$, gentral view. Scales: $a-d=5.0 \mathrm{~mm} ; \mathrm{e}-\mathrm{h}=1.0$ $\mathrm{mm}$. 
dake, Ishigaki Island, Yaeyama Islands, the Ryukyus, Japan, coll. H. Kasai, 28 August 1982 . - 1 o 41.7 by $33.9 \mathrm{~mm}$ (ZRC 1994.4452), upper reaches of the Miyara River, Ishigaki Island, Yaeyama Islands, the Ryukyus, Japan, coll. S. Shokita, June 1983.

Remarks. - Minei's (1973) description is quite detailed and there is no need to elaborate on it here. Minei (1973: 222) also reported on two males from the nearby Iriomote Island, but we have not examined specimens from there and cannot confirm if they are conspecific. Ryukyum yaeyamense is a relatively large species, reaching sizes of over $40 \mathrm{~mm}$ in carapace width. Females smaller than 30 $\mathrm{mm}$ carapace width are still immature.

Ecology. - Ryukyum yaeyamense is a terrestrial crab and does not occur in the water itself. In Ishigaki Island, $R$. yaeyamense occurs from the banks of the upper reaches of the Miyara and Nagura Rivers almost to the top of the mountain. The swollen carapace is probably adapted for air-breathing like many land crabs of the family Gecarcinidae. The crab can sometimes be found in wet terrestrial areas during the breeding season. The physiognomy of $R$. yaeyamense is similar to that of Geothelphusa levicervix from the Okinawa Group of islands. Gima \& Shokita (1980), in a study of ecological distribution of four potamid crabs on Okinawa Island, showed that $G$. levicervix inhabits mainly terrestrial habitats but sometimes occurs in wet terrestrial areas as well. Ryukyum yaeyamense probably has very similar habits.

The eggs are spherical in shape when they are in their advanced developmental stages, and have a volume of about 6.0 cubic millimetres on average. The number of eggs carried by a female varies from seven to 13 (average 10).

Acknowledgements

Many thanks are due to Mrs. H. Kasai (formerly Ms Gima) for passing us the specimens of $R$. yaeyaemense. We are grateful to Mr. J.-Y. Shy (National Ocean University, Keelung, Taiwan) for the photographs and making preliminary sketches of the gonopods. The study has been partially supported by a research grant RP900360 from the National University of Singapore and a JSPS (Japanese Society for the Promotion of Science) research/travel grant to the first author.

\section{Literature Cited}

Bott, R., 1967. Potamiden aus Ost-Asien (Parapotamon de Man, Sinopotamon n. gen., Candidiopotamon n. gen., Geothelphusa Stimpson) (Crustacea, Decapoda). Senckenbergiana biologica, 48(3): 203-220. , 1968. Potamiden aus Süd-Asien (Crustacea, Decapoda). Senckenbergiana biologica, 49: 119-130, 5 pls.

—— 1969. Flüsskrabben aus Asien und ihre Klassifikation. (Crustacea, Decapoda). Senckenbergiana biologica, 50(5/6): 359366.

, 1970. Die Süsswasserkrabben von Europa, Asien, Australien und ihre Stammesgeschichte. Eine Revision der Potamoidea und Parathelphusoidea (Crustacea, Decapoda). Abhandlungen Senckenbergischen für Naturforschenden Gesellschaft, 526: 1-338, pls. 1-58.

Dai, A. Y., \& Chen, G. X., 1979. On the freshwater crabs of Fujian province. Acta Zoologica Sinica, 25(3): 243-249, pl. 1.

,$- \&-, 1987$. A study on the genus Nanhaipotamon (Decapoda: Isolapotamidae). Acta Zootaxonomica Sinica, 12(1): 30-35.

, - Song, Y. Z., Fan, P. F., Lin, Y. G., \& Zeng, Y. Q., 1979. On new species of freshwater crabs harbouring metacercariae of lung flukes. Acta Zootaxonomica Sinica, 4(2): 122-131, pl. 1.

- \& Ng, P. K. L., 1994. Establishment of a new genus of freshwater crab, Huananpotamon (Crustacea: Decapoda: Brachyura: Potamidae) from southern China. Raffles Bulletin of Zoology, 42(3): 657-661.

Gima, H., \& Shokita, S., 1980. Distribution of potamoid crabs in the Yona River of Okinawa Island in the Ryukyus. The Biological Magazine of Okinawa, 18: 9-15.

Minei, H., 1973. Potamoid crabs of the Ryukyu Islands, with description of five new species (Crustacea, Decapoda, Potamoidea). 
Journal of the Faculty of Agriculture, Kyushu University, 17: 203-26.

, 1981. Distribution and general habitat of the freshwater crabs of Japan. In: Ecological studies of coastal marine and freshwater crabs. In: T. Yamaguchi (ed.), Report for grant-in-aid for co-operative research, 1978-1980. pp. 79-92. Ministry of Education Japan.

Miyake, S., 1983. Japanese crustacean decapods and stomatopods in colour. Vol. II. Brachyura (Crabs). Hoikusha Publishing House, Osaka, 277 pp., 64 pls.

Ng, P. K. L., \& Dudgeon, D., 1992. The Potamidae and Parathelphusidae (Crustacea: Decapoda: Brachyura) of Hong Kong. Invertebrate Taxonomy, 6: 741-768.

\& Takeda, M., 1992. The freshwater crab fauna (Crustacea, Brachyura) of the Philippines. I. The family Potamidae Ortmann, 1896. Bulletin of the National Science Museum, Tokyo, Series A, 18(4): 149-166.

Parisi, B., 1916. I Decapodi Giapponesi del Museuo di Milano. IV. Cyclometopa. Atti Societas italiano Sciences naturelle, 55: 153-190, pls. 7-11.

Rathbun, M. J., 1898. Description of three new species of freshwater crabs of the genus Potamon. Proceedings of the Biological Society of Washington, 12: 27-30, pls. 1, 2. Sakai, T., 1976. Crabs of Japan and the Adja- cent Seas. Kodansha, Tokyo. [In three volumes: English text, xxix +773 pp., Japanese text, $461 \mathrm{pp}$., plates volume, $16 \mathrm{pp}$., 251 pls.].

Shokita, S., 1990. Inland-water decapods and their distribution in Iriomotejima Island of the Ryukyu Islands. In: Study of essential factors for preservation of wildlife in Nansei Islands. pp. 305-317. The Nature Conservation Bureau of the Environment Agency, Tokyo.

, 1991. Crustacean fauna from terrestrial and inlandwater areas and its conservation in the Ryukyus. In: Study of essential factors for preservation of wildlife in Nansei Islands. pp. 394-407. The Nature Conservation Bureau of the Environment Agency, Tokyo.

Shy, J.-Y., Ng, P. K. L., \& Yu, H.-P., 1994. Crabs of the genus Geothelphusa Stimpson, 1858 (Crustacea: Decapoda: Brachyura: Potamidae) of Taiwan, with descriptions of 25 new species. Raffles Bulletin of Zoology, 42(4): 781-848.

(PKLN) Department of Zoology, National University of Singapore, Kent Ridge, Singapore 0511, Republic of Singapore; (SS) Department of Marine Sciences, University of the Ryukyus, Senbaru 1, Nishihara, Okinawa 903-01, Japan. 